\title{
Meningkatkan kemampuan guru dalam merancang dan menggunakan video pembelajaran di saat pandemi Covid-19
}

\section{Improve the ability of teachers to design and use instructional videos during the Covid-19 pandemic}

\author{
Novita Yuliarni ${ }^{1}$ \\ ${ }^{1,2}$ SDN 2 Landasan Ulin Timur \\ Email: novie.banjarbaru12@gmail.com ${ }^{1}$
}

\section{INFO ARTIKEL}

Diterima : 30 April 2021

Disetujui : 27 Mei 2021

Tersedia secara Online Mei 2021

\author{
Alamat Korespondensi: \\ Novita Yuliarni \\ SDN 2 Landasan Ulin Timur \\ Landasan Ulin Tengah, Liang Anggang, \\ Banjarbaru Kota, Kalimantan Selatan \\ E-mail: \\ novie.banjarbaru12@gmail.com
}

\begin{abstract}
ABSTRAK
Hasil pengawasan yang dilakukan di lapangan, yaitu di SDN 2 Landasan Ulin Timur, masih ada guru yang kurang optimal dalam merancang dan video pembelajaran di masa pandemi Covid 19. Melihat kondisi pembelajaran yang demikian, khususnya dalam perancangan dan penggunaan video pembelajaran, dirasa perlu untuk memberikan pembinaan kepada guru melalui Supervisi Akademik. Penelitian dilakukan di SDN 2 Landasan Ulin Timur pada semester 1 Tahun Pelajaran 2020/2021, pada bulan Oktober November 2020 (kurang lebih 2 bulan). Subjek penelitian tindakan sekolah ini adalah satu orang guru yaitu guru kelas VI B. Pengumpulan data dilakukan dengan teknik observasi, penilaian pelaksanaan proses pembelajaran, dan instrumen observasi. Prosedur yang dilakukan ialah Penelitian Tindakan Sekolah melalui 2 siklus yang setiap siklusnya dimulai dari tahap perencanaan, tindakan, observasi, dan refleksi. Hasil penelitian menunjukkan kemampuan guru dalam merancang dan menggunakan video pembelajaran mengalami peningkatan. Pada aspek administrasi (perangkat) pembelajaran terjadi peningkatan sebesar 5 poin $( \pm 6 \%)$, aspek proses belajar-mengajar (PBM) terjadi peningkatan sebesar 17,8 poin $( \pm 28 \%)$, dan aspek komponen perancangan dan penggunaan video pembelajaran terjadi peningkatan sebesar 1 poin $( \pm 40 \%)$.
\end{abstract}

Kata kunci: Supervisi Akademik, Video Pembelajaran, Pembelajaran Masa Pandemi Covid-19.

The results of supervision carried out in the field, namely at SDN 2 Landasan Ulin Timur, there were still teachers who were less than optimal in designing and learning videos during the Covid 19 pandemic. guidance to teachers through Academic Supervision. The research was conducted at SDN 2 Landasan Ulin Timur in the 1st semester of the 2020/2021 academic year, in October - November 2020 (approximately 2 months). The subject of this school action research was one teacher, namely a grade VI teacher. The data was collected by means of observation techniques, assessment of the implementation of the learning process, and observation instruments. The procedure used is School Action Research through 2 cycles, each cycle starting from the planning, action, observation, and reflection stages. The results showed that the teacher's ability to design and use instructional videos had increased. In the administrative (device) aspect of learning there was an increase of 5 points ( $\pm 6 \%)$, the aspect of the teaching-learning process (PBM) increased by 17.8 points ( \pm 28\%), and the component aspects of designing and using learning 
videos had an increase of 1 point $( \pm 40 \%)$.

Key words: cademic Supervision, Video Learning, Learning during the Covid-19 Pandemic.

\section{PENDAHULUAN}

Pandemi virus corona atau dikenal dengan Covid-19 memaksa seluruh jenjang pendidikan, sejak TK hingga Perguruan Tinggi menghentikan proses pembelajaran tatap muka. Imbas dari hal ini adalah lahirnya kebijakan pelaksanaan Pembelajaran Jarak Jauh selanjutnya disingkat PJJ berdasarkan Surat Edaran Mendikbud Nomor 4 Tahun 2020 tentang Belajar dari Rumah Melalui Pembelajaran Jarak Jauh dengan cara online atau dalam jaringan (daring).

Pembelajaran Jarak Jauh yang dilaksanakan dengan serta merta tanpa persiapan matang sebelumnya oleh semua pihak menimbulkan banyak permasalahan. Dari sisi siswa, banyak siswa siswi yang belum bisa mandiri dalam Pembelajaran Jarak Jauh (PJJ), terutama siswa SD. Mereka perlu pendampingan baik dalam penggunaan aplikasi maupun pemahaman materinya. Dari sisi orang tua, banyak orang tua yang mengeluhkan tidak menguasai materi pelajaran anak-anaknya, sehingga mereka tidak bisa mendampingi anak-anaknya belajar. Apalagi bagi orang tua yang sibuk bekerja, selain mengerjakan pekerjaannya sendiri, mereka ditambah beban untuk mengajari anak-anaknya.

Bagi guru, PJJ juga menimbulkan keresahan tersendiri, karena banyak guru-guru kita yang masih belum melek teknologi. Dengan adanya PJJ, guru harus menguasai kompetensi TIK yang sangat diperlukan untuk kelancaran PJJ. Selanjutnya dari segi fasilitas, banyak siswa kita dari menengah kebawah yang tidak mempunyai gadget atau laptop. Pembelajaran daring memaksa siswa untuk mempunyai fasilitas ini, tanpa gadget atau laptop, mereka tidak akan bisa mendapatkan informasi dan mengikuti pembelajaran jarak jauh. Selain gadget, kuota juga menjadi masalah yang sangat menyita keuangan orang tua siswa. Di masa pandemi ini, semua orang lebih mementingkan kepentingan sehari-hari daripada membeli kuota.

Hal mendasar dalam pelaksanaan PJJ adalah bagaimana menjadikan proses pembelajaran tetap menarik bagi siswa meskipun tanpa tatap muka (Mashud, Tangkudung, \& Widiastuti, 2018). Kegiatan belajar mengajar akan tetap menarik bagi siswa jika gurunya mampu menghadirkan pembelajaran yang menyenangkan dengan media yang tepat. Salah satu usaha yang diambil beberapa guru di SD Negeri 2 Landasan Ulin Timur adalah menggunakan video untuk menyampaikan materi pembelajaran kepada peserta didik. Video sebagai media audio-visual yang menampilkan gerak, semakin lama semakin populer dalam masyarakat. Video juga dianggap cukup ideal karena peserta didik bisa mengulang jika mereka belum memahami materi yang disampaikan dan bisa menyaksikan kapanpun, karena mayoritas pembelajaran dilaksanakan melalui Whatsapp.

Supervisi akademik adalah usaha yang dilakukan untuk membantu para guru mengembangkan kemampuannya mencapai tujuan pembelajaran (Bahri, 2014). Kepala sekolah melalui supervisi akademik bisa memantau sejauh mana kesiapan guru sebelum melaksanakan pembelajaran. Dalam supervisi akademik ini, kepala sekolah bisa memberikan arahan dan saran untuk ketercapaian tujuan pembelajaran. 
Beberapa laporan penelitian sebelumnya (Susetya, 2017; Jurotun et. al., 2015; Astuti, 2017; Purwanto, 2019) yang menyatakan bahwa kompetensi guru dalam merancang dan melaksanakan pembelajaran (pedagogik) dapat ditingkatkan melalui supervisi akademik. Selain itu kompetensi guru dalam merancang dan menggunakan media pembelajaran seperti video pembelajaran juga dapat ditingkatkan (Sugandi, 2019; Herlina, 2020).

Berdasarkan latar belakang tersebut penulis selaku Kepala Sekolah melakukan upaya perbaikan untuk meningkatkan mutu PJJ (Pembelajaran Jarak Jauh) melalui media video melakukan Penelitian Tindakan Sekolah dengan judul "Meningkatkan Kemampuan Guru dalam Merancang dan Menggunakan Video Pembelajaran di Saat Pandemi Covid 19 (Penelitian Tindakan Sekolah Melalui Supervisi Akademik di SDN 2 Landasan Ulin Timur)".

\section{METODE}

Penelitian dilakukan di SDN 2 Landasan Ulin Timur pada semester 1 Tahun Pelajaran 2020/2021, pada bulan Oktober-November 2020 (kurang lebih 2 bulan). Subjek penelitian tindakan sekolah ini adalah satu orang guru yaitu guru kelas VI B. Pengumpulan data dilakukan dengan teknik observasi, penilaian pelaksanaan proses pembelajaran, dan instrumen observasi. Prosedur yang dilakukan ialah Penelitian Tindakan Sekolah melalui 2 siklus yang setiap siklusnya dimulai dari tahap perencanaan, tindakan, observasi, dan refleksi.

\section{HASIL PENELITIAN}

Data hasil supervisi tentang administrasi dan proses belajar-mengajar serta perancangan dan penggunaan media (video pembelajaran) pada kedua siklus disajikan pada grafik 1.

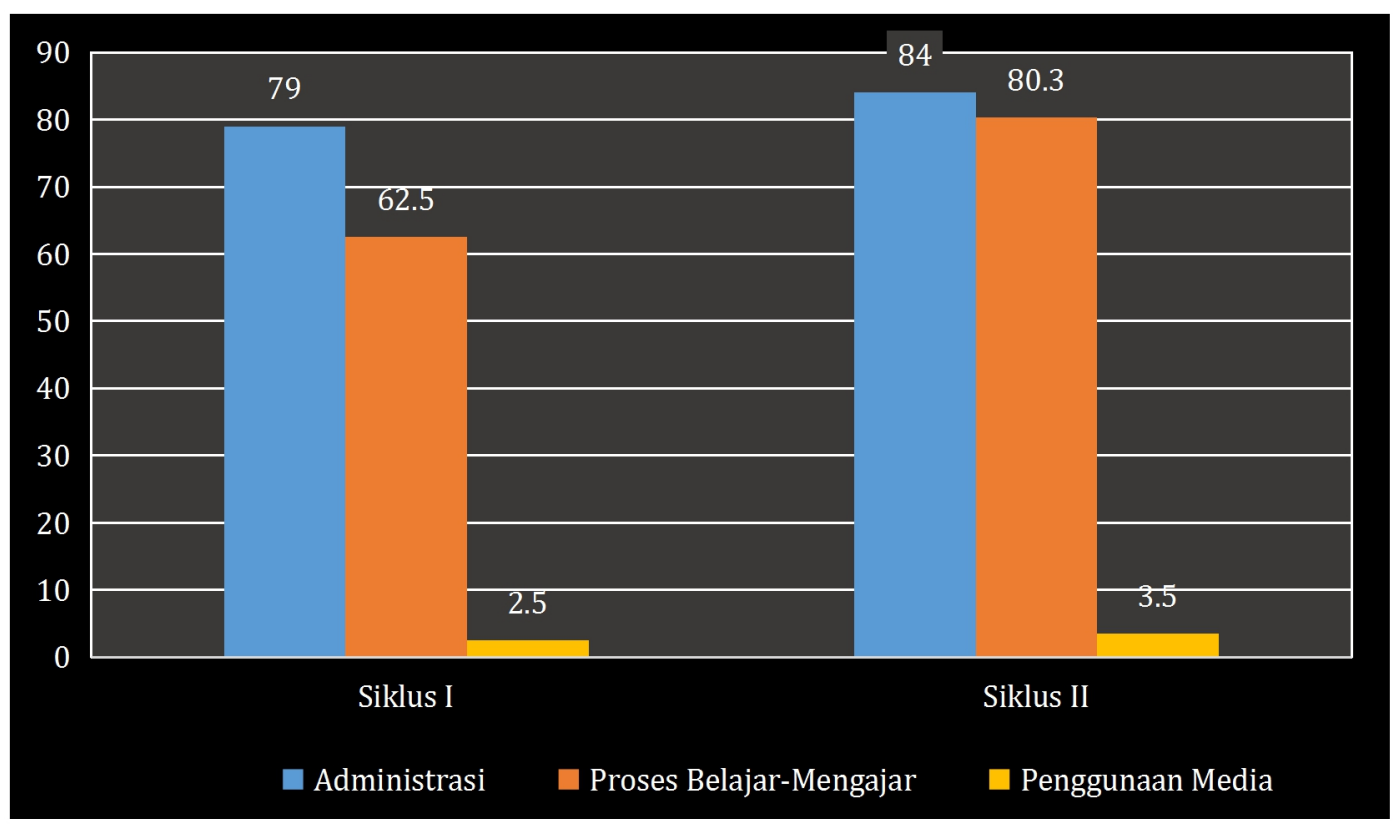

Gambar 1. Grafik Perbandingan antara Siklus I dan Siklus II

Gambar 1 menjelaskan bahwa guru kelas SDN 2 Landasan Ulin Timur yang disupervisi, untuk aspek administrasi (perangkat) pembelajaran, pada Siklus I nilainya yaitu 79 
(klasifikasi "baik"), sedangkan pada Siklus II nilainya yaitu 84 (juga klasifikasi "baik"). Dapat terlihat adanya peningkatan sebanyak 5 poin $( \pm 6 \%)$.

Adapun untuk aspek proses belajar-mengajar (PBM), pada Siklus I guru memperoleh nilai 62,5 (klasifikasi "baik"), sedangkan pada Siklus II memperoleh nilai rata-rata 80,3 (klasifikasi "baik sekali"). Berdasarkah hasil tersebut, terjadi peningkatan sebesar 17,8 poin $( \pm 28 \%)$.

Selain itu, untuk salah satu komponen aspek yang difokuskan yaitu penggunaan media dalam hal ini adalah perancangan dan penggunaan video pembelajaran, baik yang terdapat dalam aspek administrasi (perangkat) pembelajaran maupun yang terdapat dalam aspek proses belajar-mengajar (PBM), juga terdapat peningkatan antara Siklus I dengan Siklus II. Pada Siklus I, untuk komponen aspek tersebut, nilai rata-ratanya adalah 2,5 (kurang), sedangkan pada Siklus II nilai rata-ratanya adalah 3,5 (cukup). Dengan demikian, terjadi peningkatan sebesar 1 poin atau sebesar $\pm 40 \%$.

\section{PEMBAHASAN}

Observasi terhadap guru kelas VI B SDN 2 Landasan Ulin Timur dilaksanakan dalam dua siklus. Setiap siklus dilakukan dalam satu kali pertemuan (tatap muka) saja, dikarenakan keterbatasan waktu yang tersedia dan dirasa sudah cukup untuk memperlihatkan perkembangan guru yang bersangkutan. Hasil supervisi pada kedua siklus memperlihatkan adanya peningkatan untuk aspek administrasi (perangkat) pembelajaran dan aspek proses belajar-mengajar (PBM).

Supervisi akademik adalah usaha yang dilakukan untuk membantu para guru mengembangkan kemampuannya mencapai tujuan pembelajaran (Bahri, 2014). Menurut Glickman supervisi akademik adalah serangkaian kegiatan membantu guru mengembangkan kemampuannya mengelola proses pembelajaran untuk mencapai tujuan pembelajaran (Irawan et. al., 2018). Oleh karena itu, supervisi akademik penting sebagai suatu langkah untuk memperoleh data pengembangan profesionalisme guru.

Beberapa laporan penelitian sebelumnya (Susetya, 2017; Jurotun et. al., 2015; Astuti, 2017; Purwanto, 2019), yang menyatakan bahwa kompetensi guru dalam merancang dan melaksanakan pembelajaran (pedagogik) dapat ditingkatkan melalui supervisi akademik. Selain itu kompetensi guru dalam merancang dan menggunakan media pembelajaran seperti video pembelajaran juga dapat ditingkatkan (Sugandi, 2019; Herlina, 2020).

Hasil penelitian ini sejalan dengan penelitian sebelumnya (Astuti, 2017) yang mengungkapkan bahwa kompetensi guru mengalami peningkatan setelah dilakukan supervisi akademik. tingkat kompetensi penyusunan administrasi pembelajaran di SD Laboratorium menghasilkan peningkatan 26,2\% dari kondisi awal skor 63,5 setelah dilakukan supervisi menjadi 89,6. Peningkatan kompetensi guru dalam menyusun administrasi pembelajaran dapat terjadi karena peneliti dapat melakukan supervisi akademik sesuai dengan prinsipprinsip dalam melakukan supervisi seperti objektif, realistis, kekeluargaan, demokratis, dan humanis.

Supervisi akademik dilaksanakan oleh peneliti sesuai dengan aspek-aspek pada instrumen penelitian yang telah disiapkan dan tentunya berpegang pada kenyataan di lapangan. Prinsip saling asah, asih, dan asuh dalam mengembangkan perencanaan 
pembelajaran juga telah diterapkan peneliti sehingga dapat membangun hubungan dengan guru yang harmonis, terbuka, jujur, dan antusias. Oleh karena itu, kegiatan supervisi akademik dapat dilaksanakan dengan lancar dan guru juga tidak mengalami ketegangan atau bahkan takut sehingga tujuan yang diharapkan dapat tercapai.

Kepala sekolah sebagai seorang manajer mempunyai tugas dan fungsi mengoordinasikan dan menyerasikan sumber daya manusia jenis pelaksana melalui sejumlah input manajemen (Hendarman \& Rohanim, 2018). Input yang dimaksud tersebut di antaranya adalah kemampuan dalam mengatur semua aspek kurikulum yang berpengaruh di sekolah supaya terlaksana dengan baik sehingga mampu mencapai target yang diharapkan. Aspek kurikulum tersebut di antaranya seperti memberi bantuan kepada para guru dalam merencanakan, melaksanakan, dan menilai kegiatan pembelajaran telah dilakukan oleh kepala sekolah dalam penelitian ini dengan cukup baik.

Kegiatan supervisi yang dilakukan peneliti berkaitan dengan perbaikan proses belajar mengajar, baik untuk siswa maupun para guru saat pembelajaran. Ruang lingkup supervisi akademik dalam Permendiknas No. 39 tahun 2009 meliputi: 1) membina guru dalam merencanakan, melaksanakan dan menilai proses pembelajaran, 2) memantau pelaksanaan standar isi, 3) memantau pelaksanaan standar proses, 4) memantau pelaksanaan standar kompetensi kelulusan, 5) memantau pelaksanaan standar tenaga pendidik dan 6) memantau pelaksanaan standar penilaian (Mendiknas, 2009).

Selain supervisi akademik, kompetensi guru juga bisa ditingkatkan melalui pelatihan lesson study (Sugandi, 2019). Guru melalui pelatihan ini akan mendapat gambaran tentang pemanfaatan media pembelajaran. Selain itu, guru juga dapat melihat contoh pelaksanaan pembelajaran yang mudah, menarik, dan menyenangkan.

Kegiatan supervisi akademik ini mampu meningkatkan kompetensi guru dalam melaksanakan proses belajar mengajar. Peningkatan kompetensi guru pada siklus II penelitian ini terjadi karena peneliti dapat melakukan supervisi akademik sesuai dengan prinsip-prinsip dalam melakukan supervisi. Selain itu, keberhasilan guru dalam melakukan perbaikan-perbaikan proses pembelajaran berdasarkan hasil refleksi pada pelaksanaan siklus I juga menjadi faktor penyebab meningkatnya kompetensi guru.

Kemampuan guru dalam melaksanakan proses belajar mengajar telah meningkat pada penelitian ini sejalan dengan penelitian Purwanto (2019). Guru dalam supervisi penelitian tersebut mengalami peningkatan yang cukup signifikan dan hasil akhir diperoleh nilai ratarata $(85,95)$ dengan persentase ketercapaian $100 \%$. Hasil ini menunjukkan bahwa pembinaan melalui supervisi yang dilakukan kepala sekolah memiliki dampak positif terhadap kompetensi guru dalam pembelajaran.

Kemampuan guru dalam merancang dan menggunakan media yakni video pembelajaran dalam supervisi akademis ini telah meningkat dari kriteria kurang pada siklus I menjadi kriteri cukup pada siklus II. Hasil ini sejalan dengan sejumlah penelitian lain (Sugandi, 2019; Herlina, 2020). Hasil penelitian Herlina (2020) menunjukkan bahwa setelah dilaksanakan supervisi akademik, kemampuan guru SMP Negeri 2 Bungursari Kabupaten Purwakarta dalam media video pembelajaran sudah menunjukkan adanya peningkatan, dari siklus I ke Siklus II. 
Penelitian ini tidak terlepas dari adanya kendala. Kendala utama yang dihadapi peneliti tentu saja adalah pelaksanaan pembelajaran jarak jauh (daring) yang memerlukan waktu pembiasaan dan persiapan matang. Persiapan tersebut meliputi berbagai fasilitas seperti gawai, kuota internet, sinyal, kemampuan guru dan siswa dalam mengoperasikan gawai.

\section{SIMPULAN}

Berdasarkan hasil penelitian dapat disimpulkan bahwa kemampuan guru dalam merancang dan menggunakan video pembelajaran mengalami peningkatan. Pada aspek administrasi (perangkat) pembelajaran terjadi peningkatan sebesar 5 poin $( \pm 6 \%)$, aspek proses belajar-mengajar (PBM) terjadi peningkatan sebesar 17,8 poin $( \pm 28 \%)$, dan aspek komponen perancangan dan penggunaan video pembelajaran terjadi peningkatan sebesar 1 poin $( \pm 40 \%)$.

\section{DAFTAR PUSTAKA}

Astuti, S. 2017. Supervisi Akademik untuk Meningkatkan Kompetensi Guru di SD Laboratorium UKSW. Scholaria: Jurnal Pendidikan Dan Kebudayaan, 7(1), 49-59.

Bahri, S. 2014. Supervisi Akademik Dalam Meningkatkan Profesioalisme Guru. Visipena, 5(1), 100-112.

Hendarman, \& Rohanim. 2018. Kepala Sekolah sebagai Manajer: Teori dan Praktik. PT Remaja Rosdakarya.

Herlina, E. 2020. Supervisi Akademik untuk Meningkatkan Kemampuan Literasi Digital Guru SMP Negeri 2 Bungursari. Juripol, 3(1), 26-34.

Irawan, D., Wahyudin, A., \& Yanto, H. 2018. The Moderating Influence of The Academic Supervision of Teacher Competencies and Commitment Towards Organizational of Teacher Performance SMA Kesatrian 2 Semarang city, Indonesia. Educational Management, 7(1), 64-70. http://journal.unnes.ac.id/sju/index.php/eduman

Jurotun, Samsudi, \& Prihatin, T. 2015. Model supervisi akademik terpadu berbasis pemberdayaan MGPM untuk meningkatkan kompetensi pedagogik guru matematika. Jurnal Penelitian Tindakan Sekolah Dan Kepengawasan, 2(1), 27-34.

Mashud, M., Tangkudung, J., \& Widiastuti, W. (2018). Swimming Lesson Based on Interactive Multimedia. International Journal of Sports Science, 8(3), 91-96. https://doi.org/10.5923/j.sports.20180803.04

Mendiknas. 2009. Peraturan Menteri Pendidikan Nasional No. 39 Tahun 2009 tentang Pemenuhan Beban Kerja Guru dan Pengawas Satuan Pendidikan. Menteri Pendidikan Nasional.

Purwanto, I. 2019. Upaya Meningkatkan Kompetensi Guru Dalam Proses Pembelajaran Berdasarkan Kurikulum 2013 Melalui Supervisi Akademik Semester Satu Tahun Pelajaran 2017/2018 Di SMP Negeri 9 Mataram. Urnal Ilmiah Mandala Education, 5(1), 286-296. 
Sugandi, E. 2019. Upaya Meningkatkan Kompetensi Guru melalui Supervisi Akademik dan Lesson Study. Edutech, 18(1), 102-120.

Susetya, B. 2017. Meningkatkan Kemampuan Guru dalam Menyusun Silabus dan RPP melalui Supervisi Akademik di SD N Gambiran Yogyakarta Tahun 2016. Taman Cendekia: Jurnal Pendidikan Ke-SD-An, 1(2), 134-141. 